\title{
Pannonictis nestii (Galictinae, Mustelidae), a new element in the vertebrate association of the human site of Pirro Nord (Italy, Early Pleistocene)
}

\author{
Simone COLOMBERO \\ Marco PAVIA \\ Università degli Studi di Torino, Dipartimento di Scienze della Terra, \\ I-10125 Torino (Italy) \\ simone.colombero@unito.it \\ marco.pavia@unito.it \\ Lorenzo ROOK \\ Università di Firenze, Dipartimento di Scienze della Terra, \\ I-50121 Firenze (Italy) \\ lorenzo.rook@unifi.it
}

KEY WORDS

Mustelidae,

Pannonictis,

Early Pleistocene,

Pirro Nord,

Italy.
MOTS CLÉS

Mustelidae,

Pannonictis,

Pléistocène inférieur,

Pirro Nord,
Colombero S., Pavia M. \& Rook L. 2012. - Pannonictis nestii (Galictinae, Mustelidae), a new element in the vertebrate association of the human site of Pirro Nord (Italy, Early Pleistocene). Geodiversitas 34 (3): 665-681. http://dx.doi.org/10.5252/g2012n3a11

\section{ABSTRACT}

Systematic excavations in the Early Pleistocene site of Pirro Nord (Apulia, southern Italy) yielded some remains of a relatively rare mustelid belonging to the subfamily of Galictinae Reig, 1956. The taxonomy of extinct genera within this clade is controversial, especially between Pannonictis Kormos, 1931 and Enhydrictis Forsyth-Major, 1901. Nevertheless, the Pirro Nord findings are very similar to the holotype of Pannonictis nestii (Martelli, 1906) from Upper Valdarno, and closely related to the specimens from Pietrafitta and Atapuerca.

\section{RÉSUMÉ}

Pannonictis nestii (Galictinae, Mustelidae), un nouvel élément dans l'association de vertébrés du site d'occupation humaine de Pirro Nord (Italie, Pléistocène inférieur). Les fouilles systématiques dans le site du Pléistocène inférieur de Pirro Nord (Pouilles, Italie du Sud) ont livré quelques restes d'un mustélidé relativement rare appartenant à la sous-famille des Galictinae Reig, 1956. La taxonomie des genres éteints de ce clade est controversée, en particulier entre Pannonictis Kormos, 1931 et Enhydrictis Forsyth-Major, 1901. Néanmoins, les fossiles de Pirro Nord sont très similaires à l'holotype de Pannonictis nestii (Martelli, 1906) de Valdarno supérieur, et étroitement liés aux spécimens de Pietrafitta et Atapuerca. 


\section{INTRODUCTION}

The Early Pleistocene fossil vertebrates of Pirro Nord were discovered in the early 1970s (Freudenthal 1971) within the fillings of an extensive karstic network on the Gargano peninsula. Since its discovery, this site has been subjected to extensive palaeontological investigation. The vertebrate association found in the different fillings is very rich and diversified (Abbazzi et al. 1996; Arzarello et al. 2009). Some lithic artifacts have recently been found in association with the Early Pleistocene vertebrates testifying the presence of the genus Homo (Arzarello et al. 2007, 2009). The research at Pirro Nord is still in progress, with systematic excavations and studies of both vertebrate remains and lithic industry. During the excavation campaigns of the recent years (from 2007 until 2010), two hemimandibles, several isolated teeth and a humerus were found, attributable to the large-sized mustelid Pannonictis nestii (Martelli, 1906).

\section{The PirRo Nord LOCALITY}

The Early Pleistocene site of Pirro Nord (also known in the literature as "Cava Pirro" or "Cava Dell'Erba") is situated near Apricena (Foggia, southeastern Italy) on the west slope of the Gargano promontory (Figs 1; 2). This fossil site has been well known to the palaeontological community since its discovery in the early 1970s (Freudenthal 1971) and the following studies (Abbazzi et al. 1996; Arzarello et al. 2007, 2009; Pavia et al. 2012). It consists in a karstic network developed along the contact between the Mesozoic limestone and the Neogene calcarenite and filled in with continental sediment of various origins (Abbazzi et al. 1996; Pavia et al. 2010). The fissure fillings yielded a large number of fossil vertebrates, referable to two different faunal assemblages. The oldest one is referable to the Late Miocene/Early Pliocene, the other one to the Early Pleistocene. The Neogene vertebrate association, known as the "Mikrotia Fauna" is a not-balanced association characterized by strongly endemic taxa testifying the isolation of the Gargano during the Late Miocene (Masini et al. 2008). The Early Pleistocene vertebrate association is rich and highly diversified and contains more than 100 taxa of amphibians, reptiles, birds and mammals (Abbazzi et al. 1996; Arzarello et al. 2009 and references therein). This association defines the latest Villafranchian chronological unit (Pirro Nord Faunal Unit) in the Western European mammal biochronology (Gliozzi et al. 1997; Rook \& Martínez-Navarro 2010). The mammal association found at Pirro Nord contains 14 carnivore taxa, with several species of Felidae Fischer von Waldheim, 1817, representing one of the richest Early Pleistocene carnivore associations known so far (Petrucci et al. in press). The rodent association found at Pirro Nord is poorly diversified but is characterized by the presence of Microtus (Allophaiomys) ruffoi (Pasa, 1947). The Microtus Schrank, 1798 assemblage of Pirro Nord has intermediate features between the type population of M. (A.) pliocaenicus (Kormos, 1933) from the type population of Betfia II (Early Pleistocene, Hungary) and $M$. (A.) ruffoi (Marcolini et al. in press). This latter species is known from many Italian Early Pleistocene sites, all correlated with Late Villafranchian/Early Biharian biochronological unit and with "Mimomys savini-Mimomys pusillus" zone.

The palaeomagnetic analyses carried out during the 2007 and 2009 excavation campaigns revealed a reverse polarity. Thus the Pirro Nord sediments can be referred to the Matuyama reverse polarity epoch, post Olduvay event, from 1.78 to 0.79 Ma (Napoleone et al. 2003; Tema et al. 2009; Pavia et al. 2012). Some authors (Arzarello et al. 2007, 2009; Pavia et al. 2012) stated that the age of Pirro Nord should be between 1.3 and 1.7 Ma, but others (Masini \& Sala 2007; Bertini et al. 2010) suggest an age comprised between 1.2 and 1.5 Ma. Clearly, this debate is beyond the scope of our work. Nonetheless, the lithic industry found at Pirro Nord, composed by cores and flakes attributable to the Mode 1, testify that Pirro Nord is one of the European sites which can confirm the earliest presence of the genus Homo in the continent. Among the others localities we have to cite Lézignan-la-Cèbe (1.57 Ma, southern France; Crochet et al. 2009), Barranco Leon-5 (1.4 Ma); Fuente Nueva-3 (1.25 Ma, Orce Basin, Andalousia; Toro-Moyano et al. 2009) and la Sima del Elefante (c. 1.2 Ma, northern Spain; Carbonell et al. 2008). In Eastern Europe, important sites are those of Ko- 
zarnika (1.4 or 1.2-0.9 Ma, NW Bulgaria; Sirakov et al. 2010; Kahlke et al. in press) and Bogatyri/ Sinyaya Balka and Rodniki (1.2-1.6 Ma, southern Azov Sea region, Russia; Shchelinsky et al. 2010).

The excavation campaigns carried out during the past four years (2007-2010) were focused on two single fissures, P10 and P13, characterized by the large number of fossil vertebrates and lithic industry, the last one particularly abundant at P13. The two fissures are located on the south slope of the limestone quarry exploited by Casale s.r.l. and already known as Cava Pirro. In addition the two fissures are quite large and display a stratigraphic complexity, so that their exploitation allows us to collect some important information about the genesis of the deposits and the ways in which the fossil remains have accumulated. The campaigns gave us the opportunity to collect a large amount of fossil vertebrate material, particularly from the P10 fissure. This fissure is characterized by a fourmeter succession of yellowish clay sands with a one-meter conglomerate on the top, separated by a discontinuity surface (Pavia et al. 2012).

\section{GALICTINAE HISTORICAL FRAMEWORK}

The name Galictinae Reig, 1956 was established to substitute the name Grisoninae Pocock, 1921, used until that moment to describe some extant and extinct species of Mustelidae (see also Pilgrim 1932). Indeed, the name Grison Oken, 1816, genus type of Grisoninae was considered invalid (Hershkovitz 1949) being the correct one Galictis Bell, 1826. Among the other reasons of its invalidity Hershkovitz (1949) stated that Grison appears as the vernacular name and it was never proposed by Oken as a generic name. So, in accordance with the principles of art. 40 of ICZN code (see in particular art. 40.2, but see also arts 11 and 12) the valid name of the subfamily should be Galictinae.

Following the work of some authors (Reig 1956, 1957; Bjork 1970; Ray et al. 1981; Martin 1989; Baskin 2011) the Galictinae subfamily includes some extinct genera, i.e. Enhydrictis Forsyth Major, 1902, Pannonictis Kormos, 1931 from the Old World, Lutravus Furlong 1932, Cernictis Hall, 1935, Trigonictis Hibbard, 1941, Stipanicicia Reig, 1956, and Sminthosinis Bjork, 1970 from the New World

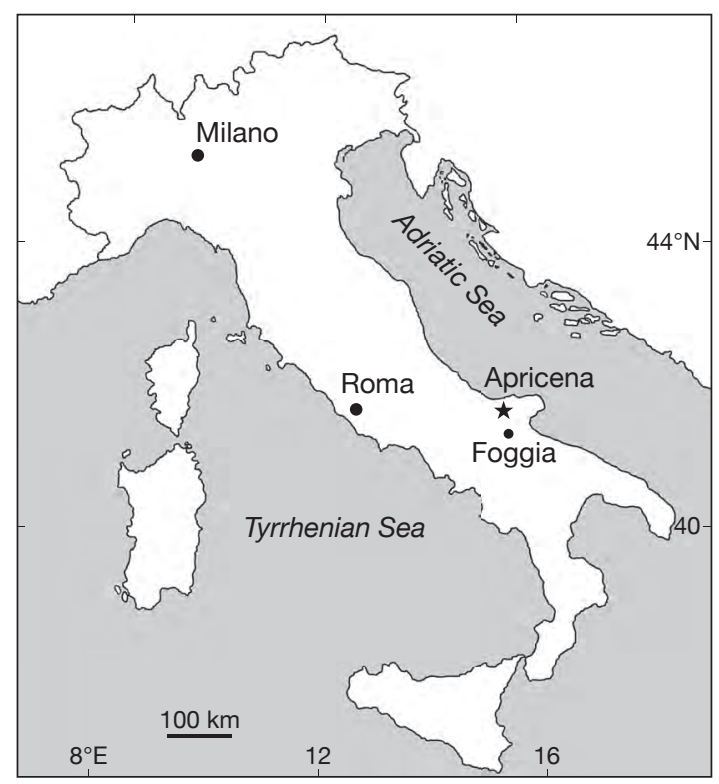

FIG. 1. - Location map of the Apricena quarries area, Italy.

and some extant genera, i.e. Galictis Bell, 1826 and Lyncodon Gervais, 1844. Baskin (1998) considered this subfamily as a tribe under the name of Galictini Baskin, 1998 belonging to Mustelinae Fischer von Waldheim, 1817. However, recent paleontological findings and new phylogenetic research point to a more complex situation. As regards the extinct genera, we have to add the Mediterranean Mustelercta De Gregorio, 1925 and the Asian genera Eirictis Qiu, 2004 and Oriensictis Ogino \& Otsuka, 2008. Moreover, in accordance with the phylogenetic analyses of Carnivora Bowdich, 1821 performed by Fulton \& Strobeck (2006), Galictinae Reig, 1956 can be considered as a consistent clade composed by some extant species diffused in South America within the genus Galictis, but present in the Old World too with the genus Ictonyx Kraup, 1835. Nevertheless, other genera, such as Lyncodon, Poecilogale Thomas, 1883 and Vormela Blasius, 1884 are closely related (Bininda-Emonds et al. 1999; Flynn et al. 2005; Koepfli et al. 2008). All of them possess "aposematically coloured pelage (i.e. black and white warning colours) combined with defence behaviours that include threat displays and excretion of pungent musk from enlarged anal 
glands" (Koepfli et al. 2008). A very recent work (Wolsan \& Sato 2010) groups together the genus Galictis with Poecilogale, Vormela and Ictonyx but refers to this clade as Ictonychinae Pocock, 1921. Nonetheless Wilson \& Reeder (2005) include Galictis and Ictonyx in Mustelinae not recognizing the validity of the subfamily Galictinae.

The European remains of the Plio-Pleistocene Galictinae have recently been reconsidered (García et al. 2008; García \& Howell 2008) in the wake of new discoveries from the paleoanthropological site of Sima de l'Elefante (García \& Howell 2008). The first report of fossil Galictinae came from ForsythMajor (1901). He described the new genus Enhydrictis and the new species E. galictoides based on a skull and a fragmentary mandible found in the Late Pleistocene deposits of Monte San Giovanni, Iglesias (Sardinia, Italy). Later, Kormos (1931) described the new genus Pannonictis based on several remains from the Plio-Pleistocene sites of Villany and Beremend (Hungary) establishing the type species Pannonictis pliocaenica Kormos, 1931. The new genus can be distinguished from Enhydrictis on the basis of the cranial morphology. Then Kormos (1933) separated the Hungarian material into two different species, Pannonictis pliocaenica and Pannonictis pilgrimi Kormos, 1933, the first being of a larger size. Later on, Schaub (1949) referred Mustela ardea Bravard, 1828 from Ardes, Perrier-Étouaires (2.5 Ma) to Pannonictis. In the same paper (Schaub 1949) the author indicated the synonymy of Proputorius olivolanus Martelli, 1906 from Olivola (Late Pliocene, Italy) with Pannonictis ardea (Bravard, 1828).

Describing the fossil mammals from Saint-Vallier, Viret $(1950,1954)$ focused on the cranium and the right hemimandible of a fossilized Mustelidae. He stated that they had characteristics in common with Enhydrictis galictoides Forsyth-Major, 1901, allowing him to use the same genus for his fossils. Then, Viret identified them as belonging to a species that could also include Pannonictis pilgrimi Kormos, 1933, Proputorius olivolanus Martelli, 1906 and Mustela ardea Bravard, 1828, synonymising all these forms in Enhydrictis ardea (Bravard, 1828).

Subsequently, Ficcarelli \& Torre (1967) supported Schaub's conclusions (1949) and indicated that
Enhydrictis can be separated from Pannonictis on the grounds of its stronger post-orbital constriction. In the same paper (Ficcarelli \& Torre 1967) the authors rejected the synonymy of Pannonictis pilgrimi with Enhydrictis ardea, because P. pilgrimi manifests a wider ascending ramus and a longer rostral length. In addition, the authors observed a great similarity between Pannonictis pilgrimi and Proputorius nestii Martelli, 1906, described from the Upper Valdarno (Late Pliocene, Italy) and no longer reported after its first description, and they suggest that it should be attributed to the genus Pannonictis, under P. nestii.

Later on, Kurtén (1968) and Willemsen (1988) again considered Pannonictis pilgrimi as synonymous with Enhydrictis ardea, while Rook (1995), studying the Galictinae from the Early Pleistocene of Pietrafitta (Italy), confirmed the validity of the characteristics pointed out by Ficcarelli \& Torre (1967) and determined the Pietrafitta remains as Pannonictis nestii.

Burgio \& Fiore (1997) reconsidered the type material of a mustelid assigned to Mustela (Mustelercta) arzilla by De Gregorio (1886, 1925). They recognized it as part of the extinct European Galictinae. In particular, they observed some significant similarities to the type specimen of Pannonictis nestii, suggesting that they could belong to the same genus.

Rabeder (1976) established the new species Pannonictis? janossyi Rabeder, 1976 from some cranial and dentary remains from Villany-Kalkberg. This species can be distinguished from the others for the small dimensions, similar to the current Galictis cuja (Molina, 1782). In the same work, describing some carnivores from Deutsch-Altenburg 2 (Austria, Early Plesistocene), he stated that Enhydrictis ardea should appertain to Pannonictis. According to him P. pilgrimi should be considered as a junior synonym of $P$. ardea. Moreover, he noted that the bulla auditoria of the species belonging to Pannonictis, in particular that of $P$. pliocaenica and $P$. ardea, were substantially different from that of Enhydrictis galictoides.

This hypothesis has been also followed by Spassov in several papers (Spassov 1997, 1998, 1999, 2000). In particular he noted that the area en- 

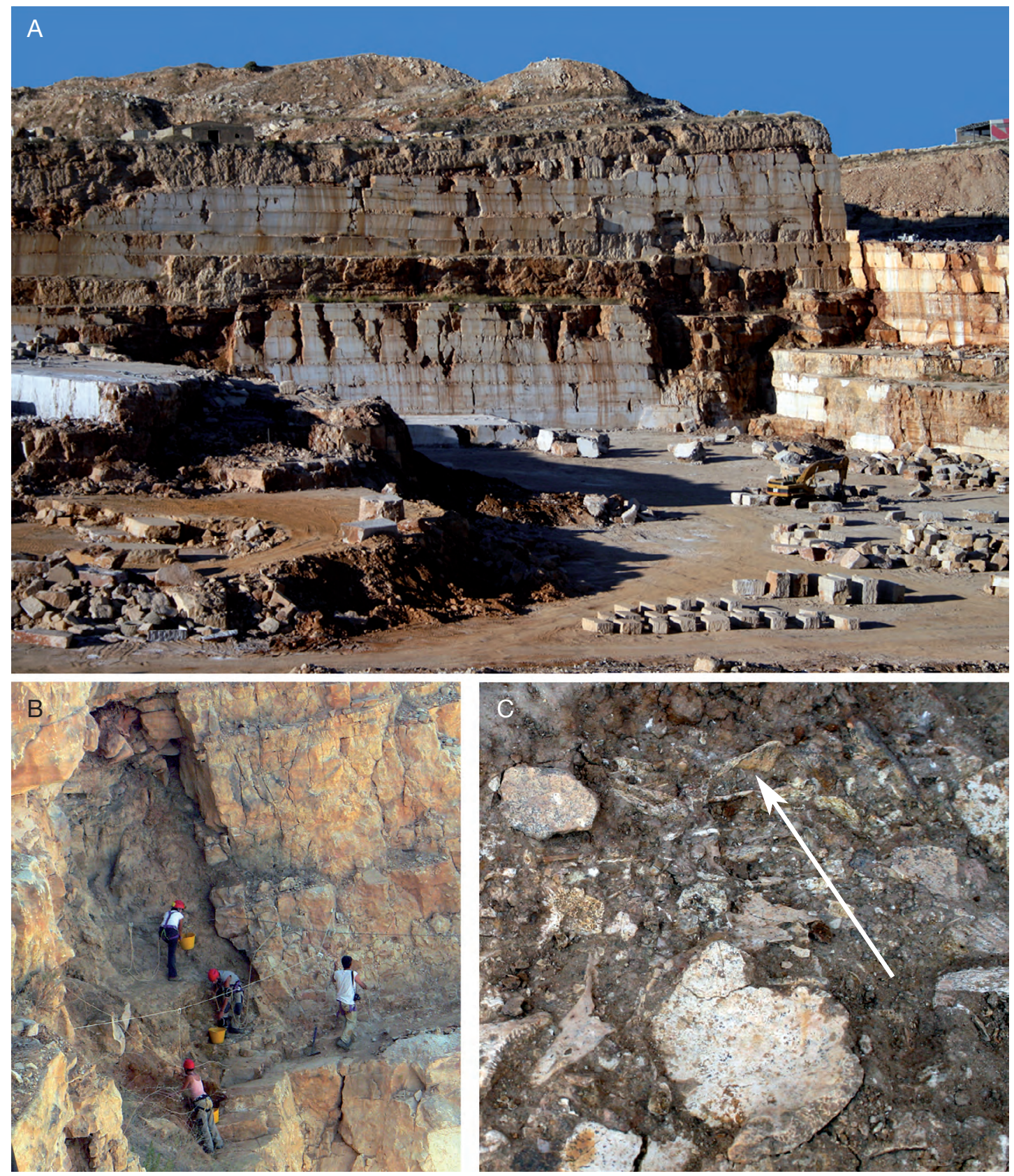

FIG. 2. - View of the Dell'Erba quarry (A) and details on the Pirro 10 fissure (B) during the excavation campaign of 2007; the hemimandible of Pannonictis nestii (Martelli, 1906) still in the sediment before removing (C, white arrow).

closed between the incisures of os palatinum and the pterygopalatine crests in Enhydrictis galictoides cranium is visibly narrower than in the crania of both "E." ardea from Saint-Vallier and Pannonictis pliocaenica from Villany (Spassov pers. comm., but see also Spassov 1999). According to him, this 
character could be important for the subdivision at a generic level. Nonetheless, Sotnikova et al. (2002) stated that E. ardea and E. galictoides are chiefly similar, having a strong postorbital constriction of the skull. Also in the view of García \& Howell (2008) the Saint-Vallier specimen described by Viret (1954) as Enhydrictis ardea, has a narrower postorbital constriction than $P$. pliocenica from Villány and $P$. nestii from Pietrafitta, although not as narrow as the Sardinian individual attributed to E. galictoides. According to them E. galictoides should be considered the only valid species within the genus Enhydrictis.

García et al. (2008) seem to consider Pannonictis nestii (= Enhydrictis ardea) as a whole group, Enhydrictis being an endemic genus of the Late Pleistocene of Sardinia (as a matter of fact the use of "Tosco-Sardinian" bioprovince by the authors is incorrect being this paleobioprovince confined to the Late Miocene endemic complex; Rook et al. 2006) with the unique species Enhydrictis galictoides. It represents a derived and local form of the Galictinae, distinct from the Pliocene and Early Pleistocene Pannonictis (García \& Howell 2008). In addition, Pannonictis pilgrimi is a synonym of $P$. pliocaenica, as the dimensional differences have been interpreted as sexual dimorphism (García \& Howell 2008).

Fejfar et al. (2012) considered P. pilgrimi as a junior synonym of $P$. ardea and attributed some remains of mustelid from Ivanovce (Early Pliocene of Slovakia) to this species. According to them, the auditory bulla of "ardea" species is more analogous to the genus Pannonictis than to Enhydrictyis.

Moreover, García et al. (2008) and García \& Howell (2008) carried out a large scale revision of the entire Eurasian fossil Galictinae dividing them into five geographical regions (East and Central Asia, Black Sea and Transcaucasian region, Southeast Europe, North and Central Europe and Mediterranean area).

Fossil remains of the genus Pannonictis have also been found in Asia (García et al. 2008 and reference therein). The species Pannonictis pachygnatha (Teilhard de Chardin \& Piveteau, 1930) was described from Nihewan, China; this species is different from other Pannonictis in its stoutness and in having the anterior margin of the $\mathrm{P}^{4}$ without any concavity. In addition, the remains of Mustelidae gen. et sp. indet. from the Upper Miocene of China (Zdansky 1927) were considered to be the oldest Pannonictis remains (Kormos 1931; Pilgrim 1932; Rook 1995; García \& Howell 2008). The fossil remains from Nihewan were studied again and attributed to the new genus Eirictis (Qiu et al. 2004). García \& Howell (2008) confirmed the validity of the morphological characteristic pointed out by Qiu et al. (2004) to distinguish Pannonictis from Eirictis on the basis of the $\mathrm{P}^{4}$ morphology.

Recently, Ogino \& Otsuka (2008) have assigned some fossils from the Middle Pleistocene of Matsugae, Japan, to the new genus Oriensictis, belonging to Galictinae.

\section{MATERIAL AND METHODS}

The Pannonictis fossil remains have been found in the various levels of the succession of the P10 fissure at Pirro Nord (Pavia et al. 2012). The specimens are kept in the Museo di Geologia e Paleontologia of the Torino University (PU).

Fossil remains have been compared with recent skeletal material of recent Mustelidae (Martes martes Linnaeus, 1758; $M$. foina Erxleben, 1777; Mustela nivalis Linnaeus, 1766; Meles meles Linnaeus, 1758), Canidae Fischer Von Waldheim, 1817 (Vulpes vulpes Linnaeus, 1758; Canis lupus Linnaeus, 1758), Felidae (Felis sylvestris Schreber, 1777; Lynx lynx Linnaeus, 1758) preserved at Museo Civico di Storia Naturale of Carmagnola (MCC) and Museo Regionale di Scienze Naturali of Torino (MRSN).

\section{SYSTEMATIC PALEONTOLOGY}

\author{
Family MUSTELIDAE \\ Fischer Von Waldheim, 1817 \\ Subfamily Galictinae Reig, 1956 \\ Genus Pannonictis Kormos, 1931
}

TYPe SPECIES. - Pannonictis pliocaenica Kormos, 1931 by original designation. 


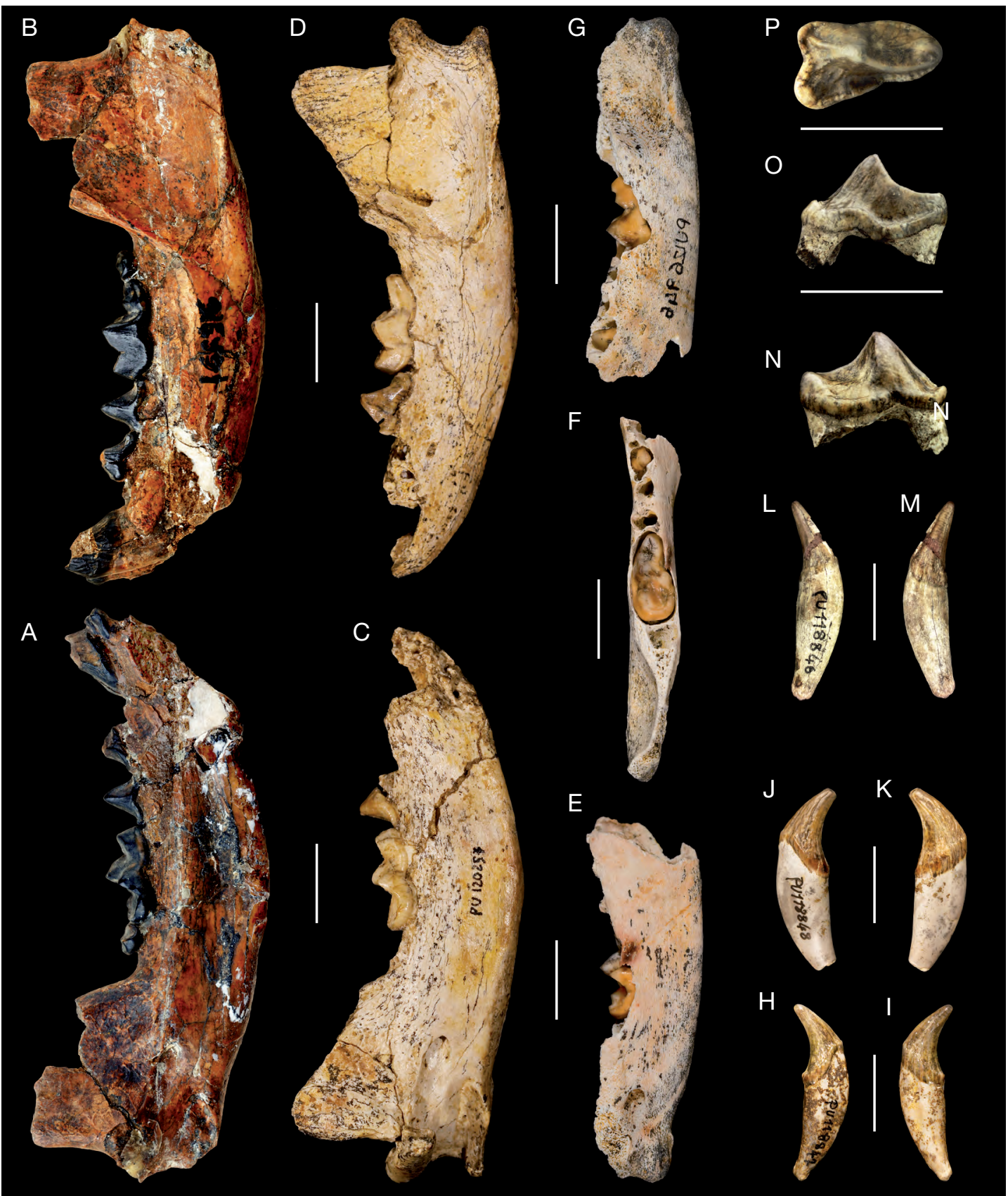

FIG. 3. - A, B, Pannonictis nestii (Martelli, 1906), holotype: left hemimandible (IGF 916) from Upper Valdarno in lingual (A) and labial (B) views; C-G, Pannonictis nestii from Pirro 10: left hemimandible (PU 120257) in lingual (C) and labial (D) views; juvenile right hemimandible (PU 126946; reversed pictures) in lingual (E), occlusal (F) and labial (G) views; H-P, Pannonictis nestii from Pirro 10: H, I, left lower canine (PU 118847) in lingual (H) and labial (I) views; J, K, right lower canine (PU 118848) in lingual (J) and labial (K) views; L, M, right upper canine (PU 118846) in lingual (L) and labial (M) views; N-P, left $P^{4}$ (PU 120242) in labial (N), lingual (O) and occlusal (P) views. Scale bars: $10 \mathrm{~mm}$. Photos of elements A and B, courtesy of Saulo Bambi (Museo di Storia Naturale, Firenze). 
Pannonictis nestii (Martelli, 1906)

(Figs 3; 4)

Proputorius nestii Martelli, 1906: 598.

Pannonictis nestii - Ficcarelli \& Torre 1967: 141. — Rook 1995: 856.

Pannonictis cf. nestii-García \& Howell 2008: 9.

Holotype. - Left hemimandible bearing $\mathrm{P}_{3}-\mathrm{M}_{2}$, from Upper Valdarno (Tuscany, Italy), housed in the Museo di Geologia e Paleontologia of the University of Florence and labeled as IGF 916.

Material examined. - Adult left hemimandible, almost complete (PU 120257); uncomplete juvenile right hemimandible (PU 126946); left lower canine (PU 118847); right lower canine (PU 118848); right upper canine (PU 118846); left P4 (PU 120242); left humerus (PU 129095).

\section{DESCRIPTION}

\section{Adult left hemimandible}

The specimen (Fig. 3C, D) is not complete in all of its parts. It lacks the coronoid process and, in the anterior part, it completely lacks the symphysis and the alveoli of the incisors are entirely absent. $M_{1}$ and $\mathrm{P}_{4}$ are the only teeth present. The horizontal branch presents a fracture, which reaches the $\mathrm{P}_{4}$ damaging the protoconid and moderately rotating the anterior part of the mandible.

The hemimandible appears stout and low. The ascending ramus is relatively wide. The angular process is somewhat thick especially in the lower part. It curves towards the medial side which presents a deep concavity. The mandibular condyle is low, slightly tilted to the dental side. No incisor is present. The canine alveolus is not complete but it suggests the presence of a large and deep root. The inferior mandibular margin descends slightly until it meets an inflection point just beneath the $M_{1}$ talonid, where it rises again gently. The masseteric fossa is very deep and extends further on the $M_{2}$ alveolus, almost reaching the $M_{1}$.

Although $\mathrm{P}_{2}$ and $\mathrm{P}_{3}$ are not present, we can observe the alveoli of these teeth occupied by the remains of their roots. They do not lie on the same line, but are slightly clockwise rotated. Thus, the posterior root of $\mathrm{P}_{2}$ is almost at the same level of the anterior root of $\mathrm{P}_{3}$, suggesting a partial over- lapping of these two teeth. As we have said, $\mathrm{P}_{4}$ is partially damaged in such a way that the anterior part of the tooth is shifted ahead, not permitting the measurement of the dental element. It has a well-pronounced protoconid, as well as a relatively well-pronounced projection of the posterior basal area where a tiny cusplet rises from enamel swells. The $M_{1}$ is very worn, with low cusps. The $M_{1}$ protoconid is stout and well developed. The paraconid is well developed too, but it shows a higher degree of wear. The metaconid is not in line with the protoconid but slightly posterior. The talonid is worn and we cannot see other accessory cusps except for a very light sign of the hypoconid. The talonid appears as a concavity with the lingual side being more consumed so that it seems to be inclined towards that part.

\section{Juvenile right hemimandible}

The specimen is not complete. It lacks completely the coronoid process. The anterior part is broken at the level of the distal part of the alveolus of the inferior canine. The hemimandible has a lighter structure compared to the adult specimen. The ascending ramus is less large than it appears in the adult form. The angular process is barely developed. The mandibular condylus is not present and we can observe only a partially preserved tiny swelling of the bone. The masseteric fossa is deep, but shorter and more shallow than in the fully developed specimen. The inferior mandibular margin is slightly bended but we cannot observe a clear inflection point. The alveolar ridge is preserved from the posterior part of the canine alveolus. Even if the canine alveolus is partially preserved, it appears large and deeply set in the mandibular body. Slightly distally, a tiny alveolus is present on the buccal side. More lingually, we can notice the erupting $\mathrm{P}_{3}$. Posteriorly two alveoli are present. Subsequently an $M_{1}$ in eruption is observable. The alveolar ridge ends with the $M_{2}$ alveolus. The $M_{1}$ paraconid is well developed even if lower than the protoconid. The metaconid is not in line with the protoconid but slightly posterior. The talonid is deep and we can observe well developed both the hypoconid and the hypoconulid. On the lingual side a tiny cusp is present developing from a low 


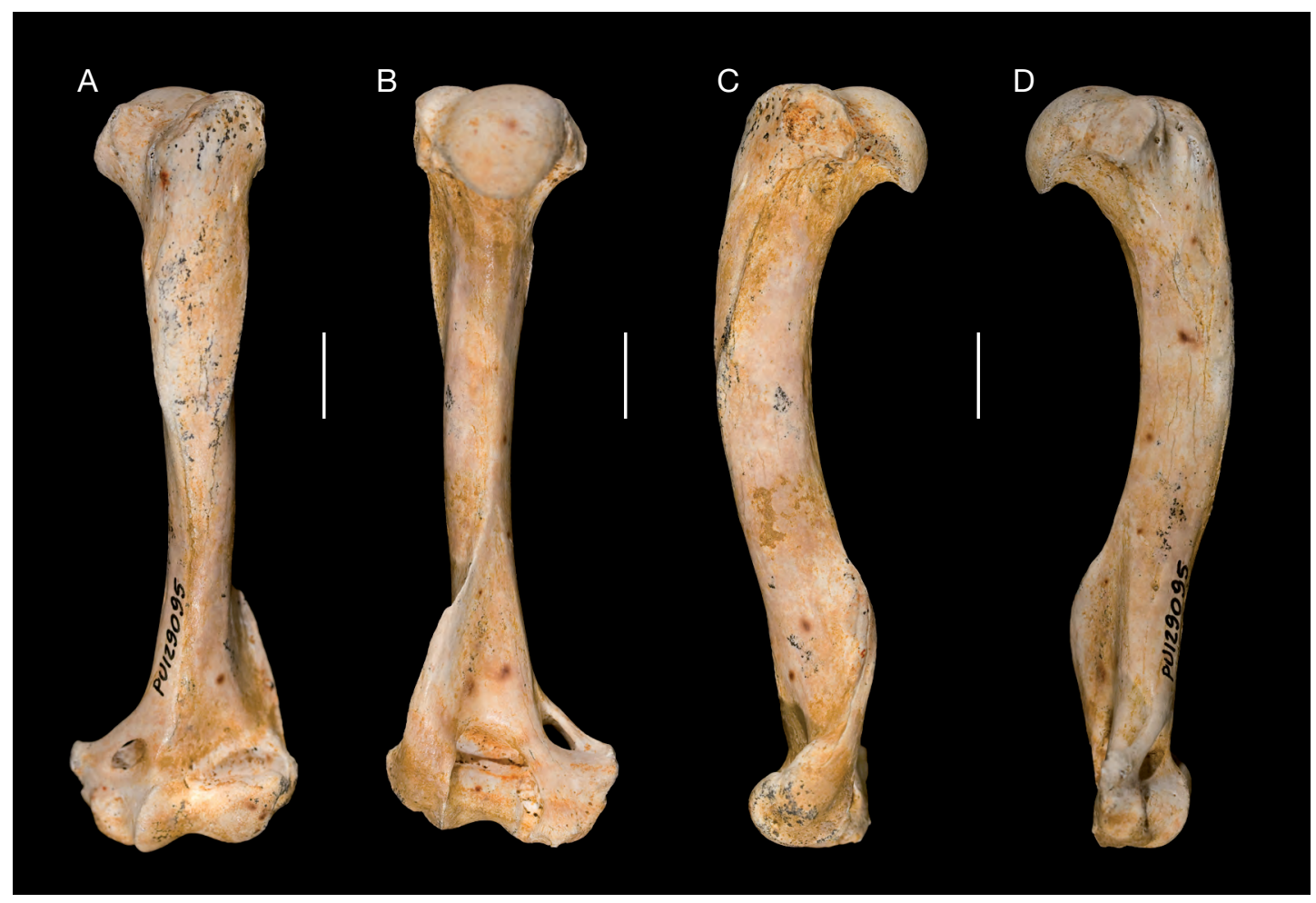

FIG. 4. - Pannonictis nestii (Martelli, 1906) from Pirro 10, left humerus (PU 129095) in anterior (A), posterior (B), lateral (C) and medial (D) views. Scale bars: $10 \mathrm{~mm}$.

margin that encloses the basin of the molar. The talonid is inclined towards the lingual side.

By comparison with the adult specimen (PU 120257) we can see that the alveolar ridge has comparable size while the posterior part is much shorter, being the whole structure less stout. This condition is also observable in the minor highness of the mandibular body, while the width has closer measures (Table 1).

\section{Lower canines}

The two lower canines show a very similar morphological pattern (Fig. 3H-K) but different dimensions (Table 1).

They have a bent shape with stout and lightly curved root. A high cingulum is clearly visible at the base of the enamel and on the internal side we can see a modest longitudinal depression that continues on the root. The enamel appears crumpled with typical wrinkles and little furrows.

\section{Upper canine}

The upper canine has a very modest degree of bending (Fig. 3L, M). Like the inferior canines, it appears crumpled and wrinkled. An anterolateral depression is present and extends for about $1 / 3$ longitudinally. A more evident groove can be observed on the anterior side, departing from the cingulum up to almost the point of the tooth. The high cingulum decreases on the lingual side.

$P^{4}$

The upper carnassial has three roots (Fig. 3N-P). The tooth is completely unworn suggesting that it could belong to a young, sub-adult individual. The paracone is the most developed cusp. It rises in the middle of the tooth, slightly displaced on the labial side. The blade departs from the paracone, gently descending and reaching the metastyle after forming a slightly curved margin. The protocone area is better represented as a 
TABLE 1. - Measurements (in mm) of Pannonictis nestii (Martelli, 1906) from Pirro Nord (Pirro 10) and other European localities. Abbreviations: $\mathbf{H M a M}_{1}$, mandibular height at $\mathrm{M}_{1}$ level; $\mathbf{W} \mathbf{M a M}_{\mathbf{1}}$, mandibular width at $\mathrm{M}_{1}$ level; $\mathbf{C}-\mathbf{M}_{\mathbf{2}}$, distance from anterior part of canine alveolus to the posterior part of $M_{2}$ alveolus; $\mathbf{M}_{1}-\mathbf{M}_{2}$, distance from anterior part of $M_{1}$ alveolus to the posterior part of $M_{2}$ alveolus; $\mathbf{L C} \mathbf{i}$, maximum length of inferior canine; $\mathbf{W C i}$, maximum width of inferior canine; $\mathbf{L M}_{1}$, maximum length of $\mathbf{M}_{1} ; \mathbf{W M}_{1}$, maximum width of $\mathbf{M} 1$; $\mathbf{L T r i M}_{1}$, trigonid length of $\mathbf{M}_{1}$; WtalM $\mathbf{M}_{1}$, talonid width of $\mathbf{M 1}$; LCS, maximum length of superior canine; WCS, maximum width of superior canine; LP4, maximum length of P4; WP4, maximum width of P4; *, juvenile individual. Data are from: 1, Rook (1995); 2, Sotnikova et al. (2002); 3 , García \& Howell (2008).

\begin{tabular}{|c|c|c|c|c|c|c|c|c|c|c|c|c|c|c|}
\hline & $\begin{array}{c}\mathrm{HMa} \\
\mathrm{M}_{1}\end{array}$ & $\begin{array}{c}\text { WMa } \\
\mathrm{M}_{1}\end{array}$ & C-M & $\begin{array}{l}M_{1-} \\
M_{2}\end{array}$ & LCi & WCi & $\mathrm{LM}_{1}$ & $\mathrm{WM}_{1}$ & $\begin{array}{l}\text { LTri } \\
M_{1}\end{array}$ & $\begin{array}{c}\text { WTal } \\
\text { M }_{1}\end{array}$ & LCS & wCs & LP4 & WP4 \\
\hline \multicolumn{15}{|l|}{ Pannonictis nestii } \\
\hline $\begin{array}{l}\text { Upper Valdarno } \\
\text { IGF } 916^{1} \text { (holotype) }\end{array}$ & 14.8 & 6.35 & 40.15 & - & - & - & 11.75 & 5.2 & - & - & - & - & - & - \\
\hline Pirro Nord PU 120242 & - & - & - & - & - & - & - & - & - & - & - & - & 10.8 & 6.2 \\
\hline Pirro Nord PU 120257 & 13.9 & 6.6 & 41.2 & 16.2 & - & _- & 12.6 & 5.6 & 8.4 & 5.2 & - & _- & - & - \\
\hline Pirro Nord PU 118846 & - & - & - & - & - & - & - & - & - & - & 6.0 & 4.6 & - & - \\
\hline Pirro Nord PU 118847 & - & - & - & - & 7.5 & 4.8 & - & - & - & - & - & - & - & - \\
\hline Pirro Nord PU 118848 & - & - & - & - & 8.7 & 5.5 & - & - & - & - & - & - & - & - \\
\hline Pirro Nord PU 126946* & 11.0 & 6.2 & - & 16.05 & - & - & 12.25 & 5.4 & 8.2 & 5.15 & - & - & - & - \\
\hline Pietrafitta 17451 & 13.25 & 6.7 & _ & - & - & _- & 12.6 & 5.55 & - & - & _- & - & _- & _- \\
\hline Pietrafitta 17491 & - & - & _- & - & - & - & - & - & _- & _- & _- & - & 10.45 & 5.9 \\
\hline Pietrafitta 17501 & 14.5 & 7.05 & 42.95 & - & - & - & 12.5 & 5.25 & - & - & - & - & - & - \\
\hline Pietrafitta 17761 & 11.95 & 5.35 & $5-$ & - & - & - & 11.50 & 4.8 & - & - & - & - & - & - \\
\hline Liventsovka RSU $98^{2}$ & 15.1 & 7.1 & - & 17.3 & - & - & 13.5 & - & - & - & - & - & - & - \\
\hline \multicolumn{15}{|l|}{ Pannonictis cf. nestii } \\
\hline $\begin{array}{l}\text { Elefante } \\
\text { ATA98-TE-J30-193 }\end{array}$ & 13.3 & 7.3 & 41.7 & 16.2 & 8.3 & 5.6 & 12.6 & 5.1 & 9.0 & 5.2 & - & - & 10.6 & 6.9 \\
\hline $\begin{array}{l}\text { Elefante } \\
\text { ATA00-TE9a-k30-103 }\end{array}$ & - & - & - & - & - & - & - & - & - & - & - & - & 11.4 & 7.4 \\
\hline $\begin{array}{l}\text { Elefante } \\
\text { ATA00-TE9-L30-543 }\end{array}$ & 14.5 & 7.7 & 46.2 & 17.9 & 10.0 & 6.4 & 14.0 & 5.2 & 9.7 & 5.2 & - & - & - & - \\
\hline
\end{tabular}

concavity surrounded by enamel swelling forming a cingulum. A very little cusplet rises from the enamel. The cingulum continues on the lingual side creating a very low hypocone. When the cingulum reaches the medial point of the tooth, it descends rapidly and then rises up again, forming an evident inflectional point. Then it almost reaches the metastyle. On the buccal side there is a light cingulum that follows the lower margin of the dental crown.

\section{Left humerus}

A magnificently preserved left humerus (Fig. 4) provides further evidences on the postcranial skeleton anatomy of Pannonictis.

The diaphysis has a straight appearance in anterior view, while in lateral (and medial) view it is markedly curved backwards and, in its distal end, frontally. The latter curvature is given by the expanded epicondylar (or supinator) crest (Fig. 4).
The proximal epiphysis has a round articular head, projected cranially. The diaphysis is transversely compressed and marked by strong ridges: the deltoid ridge is distinct and strong. The pectoral ridge is less stronger than the deltoid one and is present almost throughout the length of the diaphysis. The lateral epicondylar (or supinator) crest is laterally very expanded and extends proximally from the margin of the lateral ecycondyle to reach about $2 / 3$ of the diaphisys. In medial and lateral views it contributes the pronounced curved lateral profile (Fig. 4C, D).

On the proximal end, the lesser tuberosity is large and is separated from the greater tuberosity by a marked deep intertubercular groove.

The articulation of the distal epiphysis is wide. The capitulum (or medial condyle; for articulation with the radial head) is relatively wide on the anterior face. The trochlea (or lateral condyle) is 
narrow and relatively deep. The olecranon fossa is deep and wide. The supracondylar foramen is large, elongated proximo-distally. The radial fossa is deep and wide. The lateral epicondyle is much less laterally extended than the medial one, but it is antero-posteriorly developed and prominent due to the distal extension of the above-mentioned welldeveloped epicondylar crest. The medial epicondyle is well developed and extended medially.

\section{COMPARISON AND DISCUSSION}

In accordance with García \& Howell (2008), the presence of a small hypocone on $\mathrm{P}^{4}$ of the Pirro Nord specimen allows excluding the Asian genus Eirictis.

The genus Oriensictis from the Middle Pleistocene of Matsugae, Japan (Ogino \& Otsuka 2008) is clearly different from the Pirro Nord specimen. Indeed, in the Matsugae remains we cannot observe a basal cingulum on the lingual side of $\mathrm{M}_{1}$ while the talonid has distinct rounded marginal cusps as hypoconid and entoconid. Beside the $\mathrm{M}_{2}$ seems to be in a higher position so that the height of the horizontal ramus is greater than in the Pirro Nord specimen (Ogino \& Otsuka 2008: fig 2). The $P^{4}$ has a very well-distinguished hypocone that in our specimen is just a tiny swelling of the enamel.

With regards to the differences between "Enhydrictis" ardea and Pannonictis nestii, we can observe that the two forms have similar dimensions (Tables 1;2), even if Pannonictis nestii is generally slightly larger. Nevertheless, our scanty material cannot produce absolutely a decisive evidence to the putative synonymy of these two forms as García et al. (2008) seem to have suggested considering Pannonictis nestii (= Enhydrictis ardea) as a whole group. Besides, even if there was a possibility that the "ardea" form appertain to Pannonictis rather than Enhydrictis, these conclusions should be beyond the scope of our work. Nonetheless, as pointed out by many authors (see Ficcarelli \& Torre 1967; Rabeder 1976; Rook 1995; Spassov 1999; Sotnikova et al. 2002; García \& Howell 2008) the morphological differences between the two genera Enhydrictis and Pannonictis should be found in the neurocranial and facial bones of the cranium especially in the shape of the bulla auditoria, in the area enclosed between the incisures of os palatinum

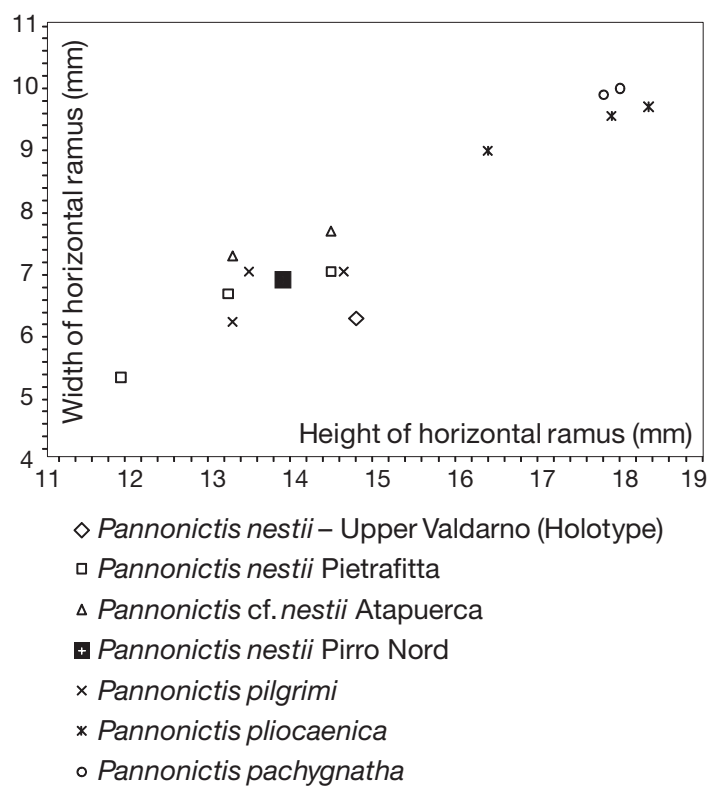

FIG. 5. - Scatter diagram of hemimandibles of different specimens. Measures (in mm) taken at $\mathrm{M}_{1}$ level. Measurements of Pannonictis nestii (Martelli, 1906) holotype, P. nestii from Pietrafitta are from Rook (1995). Measurements of $P$. cf. nestii from Atapuerca are from García \& Howell (2008). Measurements of $P$. pilgrimi Kormos, 1933 and P. pliocaenica Kormos, 1931 are from Kormos (1931, 19331934). Measurements of $P$. pachygnatha (Teilhard de Chardin \& Piveteau, 1930) are from Teilhard de Chardin \& Pivetau (1930).

and the pterygopalatine crests and in the postorbital constriction. In any case, the adult left hemimandible of Pirro Nord shows a robust mandibular body (Table 1) with a wide ascending ramus thus resulting very similar to the hemimandibles from Pietrafitta (Rook 1995), Upper Valdarno (Martelli 1906) and Atapuerca (García \& Howell 2008), all assigned to Pannonictis nestii.

Following Kormos (1931), in one mandible of Enhydrictis galictoides "collected by Forsyth-Major at San Giovanni probably after having published the description of the skull" the $M_{1}$ has the metaconid placed in one line with the protoconid, which is not the case of the Pirro Nord specimen where the first cusp is more posteriorly placed. In addition, Enhydrictis galictoides has to be excluded after the endemic characteristics showed by this species (Ficcarelli \& Torre 1967), and its limited distribution to insular Sardinia. 
TABLE 2. - Measurements (in mm) of "Enhydrictis" ardea (Bravard, 1828), Pannonictis pliocaenica Kormos, 1931 and $P$. ? janossyi Rabeder, 1976 from various European localities. Abbreviations: see Table 1. Measurements of bones that are slightly worn or damaged are indicate with an asterisk (*). Data are from: ${ }^{1}$, Rook (1995); ${ }^{2}$, Rabeder (1976); ${ }^{3}$, Viret (1954); ${ }^{4}$, Willemsen (1988); ${ }^{5}$, Schaub (1949); 6, Fejfar et al. (2012).

\begin{tabular}{|c|c|c|c|c|c|c|c|c|c|c|c|c|c|}
\hline & $\begin{array}{c}\mathrm{HMa} \\
\mathrm{M}_{1}\end{array}$ & $\begin{array}{c}\text { WMa } \\
\mathrm{M}_{1}\end{array}$ & $\mathrm{Ci}-\mathrm{M}_{2}$ & LCi & WCi & $\mathrm{LM}_{1}$ & $\mathrm{WM}_{1}$ & $\begin{array}{l}\text { LTri } \\
M_{1}\end{array}$ & $\begin{array}{c}\text { WTal } \\
M_{1}\end{array}$ & LCS & wCS & LP4 & WP4 \\
\hline \multicolumn{14}{|l|}{ Pannonictis pliocaenica } \\
\hline Beremend U.P. 6061 & 13.3 & 6.25 & 38.9 & - & - & 11.8 & - & - & - & - & - & 10.5 & - \\
\hline Villany O.B. 35941 & - & - & - & - & - & - & - & - & - & - & - & 13.2 & 8.3 \\
\hline Villany O.B. 35961 & 15.9 & - & 50.0 & - & - & 15.3 & 6.8 & 9.7 & - & - & - & - & - \\
\hline Villany O.B. 36001 & - & - & - & - & - & 15.4 & 6.3 & 10.7 & - & - & - & - & - \\
\hline Villany-Kalkberg U.P. 1291 & 13.65 & - & 50.4 & - & - & 15.9 & - & - & - & - & - & 11.5 & - \\
\hline Villany-Kalkberg U.P. 1321 & - & - & - & - & - & - & - & - & - & - & - & 12.55 & 8.7 \\
\hline Villany-Kalkberg U.P. 1341 & 18.35 & 9.7 & - & - & - & 15.45 & 6.35 & 10 & - & - & - & - & - \\
\hline Villany-Kalkberg U.P. 1351 & 13.15 & 7.05 & 45.15 & - & - & 13.5 & 5.35 & 8.05 & - & - & - & - & - \\
\hline Villany-Kalkberg U.P. 1491 & - & - & - & - & - & - & - & - & - & - & - & 12.0 & 7.6 \\
\hline Villany-Kalkberg U.P. 7651 & - & - & - & - & - & - & - & - & - & - & - & 11.2 & 7.25 \\
\hline Villany-Kalkberg U.P. 7661 & - & - & - & - & - & - & - & - & - & - & - & 10.7 & 7.8 \\
\hline Villany-Kalkberg U.P. 7671 & 17.9 & 9.55 & 54.0 & - & - & 15.95 & 6.55 & 11.05 & - & - & - & - & - \\
\hline Villany-Kalkberg U.P. 7681 & 14.55 & 7.55 & 45.15 & - & - & 13.55 & 5.35 & 8.85 & - & - & - & - & - \\
\hline Villany-Kalkberg U.P. 7691 & 16.4 & 9.0 & 53.6 & - & - & 15.7 & 6.6 & 10.85 & - & - & - & - & - \\
\hline $\begin{array}{l}\text { Pannonictis? janossyi } \\
\text { Villany-Kalkberg V61/13902 }\end{array}$ & - & - & - & - & - & - & - & - & - & - & & 7.0 & - \\
\hline \multicolumn{14}{|l|}{ "Enhydrictis" ardea } \\
\hline Saint Vallier QVS $149^{3}$ & - & - & - & - & - & 11.8 & - & - & - & - & - & - & - \\
\hline Saint Vallier QVS 1503 & - & - & - & - & - & - & - & - & - & - & - & 10.4 & - \\
\hline Tegelen ZMA4 & - & - & - & 8.1 & 5.5 & - & - & - & - & - & - & - & - \\
\hline Tege & - & - & - & 7.4 & 4.5 & - & - & - & - & - & - & - & - \\
\hline Tegelen $721158^{4}$ & - & - & - & - & - & 12.7 & 5.2 & $12.0^{*}$ & $6.0^{*}$ & - & - & - & - \\
\hline Còte d'Arde U.P. 7495 & - & - & - & - & - & 11.6 & 4.96 & - & - & - & - & - & - \\
\hline $\begin{array}{l}\text { Deutsch-Altenburg } \\
22275 / 141242\end{array}$ & 13.3 & - & - & - & - & 12.6 & 5.2 & - & - & - & - & - & - \\
\hline $\begin{array}{l}\text { Deutsch-Altenburg } \\
22275 / 14127^{2}\end{array}$ & - & - & - & - & - & 12.2 & 5.1 & - & - & - & - & - & - \\
\hline $\begin{array}{l}\text { Deutsch-Altenburg } \\
22275 / 141292\end{array}$ & - & - & - & - & - & - & - & - & - & - & - & 9.3 & 5.6 \\
\hline Z263926 & 12.9 & - & _- & 7.1 & 5.3 & 12.0 & 5.0 & 6.7 & 5.0 & _- & - & - & - \\
\hline Ivanovce Z263936 & 10.5 & - & - & & & 11.4 & 4.8 & 5.4 & 4.8 & - & - & - & - \\
\hline Ivanovce Z263946 & - & - & - & - & - & - & - & - & - & 7.0 & 4.8 & - & - \\
\hline Ivanovce Z263956 & - & _- & _- & _- & _- & _- & - & _- & - & 6.4 & 5.0 & _- & _- \\
\hline
\end{tabular}

The Pirro Nord fossils and Pannonictis pachygnatha (Teilhard de Chardin \& Piveteau 1930) present different features especially for the size which is larger in the latter. Besides, the anterior edge of $\mathrm{P}^{4}$ of $P$. pachygnatha is straight while in the specimen from Pirro Nord it is divided in two lobes.

Pannonictis? janossyi from Villany-Kalkberg (Rabeder 1976) is clearly distinguishable from the Pirro Nord remains for the smaller size (Table 2).

The fossil remains from Pirro Nord are similar in dimension to Pannonictis pilgrimi (P. pliocaenica according to García \& Howell [2008]) (Fig. 5), while they are clearly smaller than $P$. pliocaenica (Kormos 1931, 1933) (Table 2). In accordance with García \& Howell (2008), P. pilgrimi has to be considered a synonym of $P$. pliocaenica as no morphological differences have been found and size differences have to be regarded as sexual dimorphism.

None of the Galictinae remains from the Mediterranean area show similar dimension to Pannonictis pliocaenica (Kormos 1931, 1933; García \& 
Howell 2008; Table 2), testifying that this species is distinctive of the Pannonian Basin.

The adult specimen from Pirro Nord (PU 120257) is fully comparable to the holotype mandible (IGF 916) of Proputorius nestii Martelli, 1906 (Fig. 3A, B), later referred to Pannonictis (Ficcarelli \& Torre 1967). Indeed, there is an almost perfect congruence in every structure such as the stoutness of the mandibular body, the width of the ascending ramus, the position of the inflection point of the horizontal branch in the mandible, placed at the level of $\mathrm{M}_{1}$ talonid and the position of dental elements. The measurements of the two specimens are also very similar (Table 1). Moreover, the Pirro Nord specimens are not distinguishable from the specimens of Pannonictis nestii described from the Early Pleistocene of Pietrafitta (Rook 1995) and they have much in common with the material recently reported from the Early Pleistocene of Atapuerca and attributed to Pannonictis cf. nestii (García \& Howell 2008), with the exception of minor details, as the cusp of $\mathrm{P}_{4}$, which is more centrally placed in the Spanish specimen.

On the basis of our comparative analysis, the Pirro Nord specimen can be referred to Pannonictis nestii (Martelli, 1906).

De Gregorio (1886) described a fossil vertebrate association with some endemic mammals and reptiles from the Early Pleistocene of Monte Pellegrino, Sicily (Burgio \& Fiore 1997). Among them there is a Galictinae species, described as Mustela (Mustelercta) arzilla by De Gregorio (1886, $1925)$ and then analyzed again by Burgio \& Fiore (1997). In particular, the latter authors underlined the similarities of the samples with Pannonictis nestii from Upper Valdarno, comparing directly the fossil specimens (Burgio \& Fiore 1997: fig. 3). Upon comparison of the mandible from Pirro Nord with the one described from the Sicilian locality, the width of the ascending ramus, the height of the horizontal branch and the dimension of the dental elements are similar. Nevertheless, some details are different, for example the lower margin of the horizontal branch is less curved. The differences between the continental specimens and the insular forms can be explained with reference to the endemic characteristics of the latter one,
TABLE 3. - Measurements (in mm) of Pannonictis nestii from Pirro Nord (Pirro 10) (Humerus). Abbreviations: GL, greatest length of the humerus; Bp, greatest breadth of the proximal end; Bd, greatest end of the proximal end; SD, smallest breadth of diaphysis. Measures were taken following Von der Driesch (1976).

\begin{tabular}{lcccc}
\hline & GL & Bp & Bd & SD \\
\hline $\begin{array}{l}\text { Pannonictis nestii } \\
\text { Pirro Nord PU 129095 }\end{array}$ & 84.82 & 18.85 & 26.09 & 7.55 \\
\hline
\end{tabular}

which shares with the whole Monte Pellegrino vertebrate association (Kotsakis 1985). In accordance with the arguments by Burgio \& Fiore (1997), we recognize that the two forms belong to the same genus. Nonetheless, we suggest to maintain the subgeneric distinction for the endemic Sicilian form of Monte Pellegrino which should be indicated as Pannonictis (Mustelercta) arzilla (De Gregorio, 1886).

Locomotion interpretation based on postcranial characters of extinct carnivores is always a difficult task (Van Valkenburgh 1985, 1987; Peigné et al. 2008).

Inferring the locomotion of Pannonictis would require a revision of the entire available postcranial material for this taxon, in order to describe and revise all postcranial characters particularly specialized for habit and locomotion specialization. The anatomical characteristics of the complete humerus recently collected at Pirro Nord allow us to evidence the occurrence of some "aquatic" characters such as marked curvature of the diaphysis (the strong curvature of the humerus provides a better mechanical strength for resistance against flexion; Willemsen 1992). Such a character, however, contrasts with other non-aquatic humerus traits like, e.g., the slenderness of humerus, the large size of the supinator crest, and the development of medial epicondyle (large medial epicondyles are characteristic of carnivorans that climb and dig; Taylor 1974).

\section{CONCLUSIONS}

The specimens of Pannonictis nestii here described add a new element to the very rich and diversified 
Pirro Nord vertebrate association (Arzarello et al. 2009). Remains of this taxon are not common. It has been previously reported from the Late Pliocene of Upper Valdarno (Martelli 1906) and from the Early Pleistocene of Pietrafitta (Rook 1995). The Pirro Nord specimens represent the last occurrence of the taxon in Italy.

With regards to palaeoecological aspects, Rook (1995) had hypothesized an aquatic adaptation and a lifestyle linked to humid habitats as it happens in extant Galictinae in South America. Nevertheless, García \& Howell (2008) did not find reliable evidence of an aquatic lifestyle in the cranial features. The revised anatomical characteristics of Pannonictis humerus does not allow however to definitely exclude an aquatic lifestyle for his taxon. The question of locomotor adaptations and lifestyle of Pannonictis is, in our view, a still open question.

A taxonomic revision of extinct Galictinae is required in order to construct a clear phylogenetic history of this mustelid group. In particular, it would be necessary to analyze the relationships between the European genera Enhydrictis and Pannonictis which are clearly close to each other.

\section{Acknowledgements}

This study was financially supported by University Ministry grants MIUR PRIN 2009MSSS9L_002 (resp. G. Pavia, Torino) and by Italcementi Group, Cassa di Risparmio di Torino Foundation, Compagnia di San Paolo Foundation. Field works at Pirro Nord were also supported by the Municipality of Apricena and by the quarry owner, particularly V. Zuccarino (Major of Apricena), A. Verni, L. Gervasio, F. Dell'Erba and G. Dell'Erba. Appreciation is expressed to Elisabetta Cioppi (Museo di Storia Naturale sezione Geologia e Paleontologia, Firenze) for facilitating access to the holotype of Pannonictis nestii, and Saulo Bambi (Museo di Storia Naturale, Firenze) for the photos in Figure 3, particularly A and $\mathrm{B}$.

We also would like to thank the referees Nikolai Spassov, Stéphane Peigné and Annemarie Ohler for their peer review and the useful suggestions, which definitely improved the manuscript.

\section{REFERENCES}

AbBazzi L., Benvenuti M., Boschian G., Dominici S., Masini F., Mezzabotta C., Rook L., Valleri G. \& Torre D. 1996. - The Neogene and Pleistocene succession, and the mammal faunal assemblages of an area between Apricena and Poggio Imperiale (Foggia, Italy). Memorie della Società Geologica Italiana 51: 383-402.

Arzarello M., Marcolini F., Pavia G., Pavia M., Petronio C., Petrucci M., Rook L. \& Sardella R. 2007. - Evidence of earliest human occurrence in Europe: the site of Pirro Nord (southern Italy). Naturwissenschaften 94: 107-112.

Arzarello M., Marcolini F., Pavia G., Pavia M., Petronio C., Petrucci M., Rook L. \& Sardella R. 2009. - L'industrie lithique du site pléistocène inférieur de Pirro Nord (Apricena, Italie du sud) : une occupation humaine entre 1,3 et 1,7 Ma. L'Anthropologie 113 (1): 47-58.

BASKIN J. A. 1998. - Mustelidae, in JANIS C. M., SCOTT K. M. \& JACOBS L. L. (eds), Evolution of Tertiary Mammals of North America. Volume 1. Terrestrial Carnivores, Ungulates, and Ungulatelike Mammals. Cambridge University Press, London: 152-173.

BASKIN J. A. 2011. - A new species of Cernictis (Mammalia, Carnivora, Mustelidae) from the Late Miocene Bidahochi Formation of Arizona, USA. Palaeontologia Electronica 14 (3) 26A: 1-7.

Bertini A., Ciaranfi N., Marino M. \& Palombo M. R. 2010. - Proposal for Pliocene and Pleistocene land-sea correlation in the Italian area. Quaternary International 219: 95-108.

Bininda Emonds O. R. P., GitTleman J. L. \& PuRVIS A. 1999. - Building large trees by combining phylogenetic information: a complete phylogeny of the extant Carnivora (Mammalia). Biological Reviews 74 (2): 143-175.

BJORK P. R. 1970. - The Carnivora of the Hagerman Local Fauna, (late Pliocene) of southwestern Idaho. Transactions of the American Philosophical Society, new series 60 (7): 1-54.

Bravard A. 1828. - Monographie de la montagne de Perrier et de deux espèces fossiles du genre Felis. Dufour et Docagne, Paris, 146 p.

BuRgIO E. \& FIORE M. 1997. - Mustelercta arzilla (De Gregorio 1886) un elemento villafranchiano nella fauna di Monte pellegrino (Palermo, Sicilia). Il Quaternario 10 (1): 65-74.

Carbonell E., Bermudez de Castro J. M., Parés J. M., Pérez-Gonzalez A., Cuenca-Bescos G., Ollé A., Mosquera M., Huguet R., Van der Made J., Rosas A., Sala R., Vallverdu J., García N., Granger D. E., MARTinON-Torres X. P. RodrigueZ G. M., Stock J. M., Vergès E., Allué F., Burjachs I., Caceres A., Canals A., Benito M., Diez C., 
Lozano M., Mateos A., Navazo M., Rodriguez J., Rosell J. \& Arsuaga J. L. 2008. - The first hominin of Europe. Nature 452: 465-470.

Crochet J.-Y., Welcomme J.-L., IVOrRa J., RufFet G., Boulbes N., Capdevila R., Claude J., Firmat C., Métais G., Michaux J. \& Pickford M. 2009. Une nouvelle faune de vertébrés continentaux, associée à des artefacts dans le Pléistocène inférieur de l'Hérault (sud de la France), vers 1,57 Ma. Comptes Rendus Palevol 8: 725-736.

De Gregorio A. 1886. - Intorno ad un deposito di roditori e di carnivori sulla vetta di Monte Pellegrino. Atti della Società Toscana di Scienze Naturali 8 (1):3-39.

De Gregorio A. 1925. - Mammiferi quaternari in Sicilia. Annales de Géologie et de Paléontologie 43: 3-18.

FicCARELli G. \& Torre D. 1967. — Il mustelide Enhydrictis galictoides del Pleistocene della Sardegna, Palaeontographia Italica 33: 139-160.

Fejfar O., Sabol M. \& Tóth C. 2012. - Early Pliocene vertebrates from Ivanovce and Hajnáčka (Slovakia). VIII. Ursidae, Mustelidae, Tapiridae, Bovidae and Proboscidea from Ivanovce. Neues Jahrbuch für Geologie und Paläontologie 264 (2): 95-115.

FlynN J. J., Finarelli J. A., Zehr S., Hsu J. \& Nedbal M. A. 2005. - Molecular phylogeny of the Carnivora (Mammalia): assessing the impact of increased sampling on resolving enigmatic relationships. Systematic Biology 54: 317-337.

FORSYTH-MAJOR C. I. 1901. - On Enhydrictis galictoides, a new fossil from Sardinia. Proceedings of the Zoological Society of London 2: 625-628.

FREUDENTHAL M. 1971. - Neogene vertebrate from the Gargano Peninsula, Italy. Scripta Geologica 14: 1-10.

Fulton T. L. \& Strobeck C. 2006. - Molecular phylogeny of the Arctoidea (Carnivora): effect of missing data on supertree and supermatrix analyses of multiple gene data sets. Molecular Phylogenetics and Evolution 41: 165-181.

García N. \& Howell F. 2008. - New discovery of a large mustelid - Pannonictis cf. nestii - (Carnivora: Mammalia) from the early Pleistocene locality of Sima del Elefante (Sierra de Atapuerca, Spain). Palaeontographica, Abteilung A: Palaozoologie-Stratigraphie 284: 1-16.

García N., Arsuaga J. L., Bermúdez de Castro J. M., Carbonell E., Rosas A. \& Huguet R. 2008. The Epivillafranchian carnivore Pannonictis (Mammalia, Mustelidae) from Sima del Elefante (Sierra de Atapuerca, Spain) and a revision of the Eurasian occurrences from a taxonomic perspective. Quaternary International 179: 42-52.

Gliozzi E., Abbazzi L., Argenti P., Azzaroli A., Caloi L., Capasso Barbato L., Di Stefano G., Esu D., Ficcarelli G., Girotti O., Kotsakis T., Masini F., Mazza P., Mezzabotta C., Palombo M. R., Petronio C., Rook L., Sala B., Sardella R.,
Zanalda E. \& Torre D. 1997. - Biochronology of selected mammals, molluscs and ostracods from the Middle Pliocene to the Late Pleistocene in Italy. The state of the art. Rivista Italiana di Paleontologia e Stratigrafia 103: 369-388.

HeRSKOVITZ P. 1949 - Status of names credited to Oken, 1816. American Society of Mammalogists 30 (3): 289-301.

KahlKe R.-D., García N., Kostopoulos D., LacomBat F., Lister A., Mazza P., Spassov N. \& Titov V. 2011. - Western Palaearctic palaeoenvironmental conditions during the Early and early Middle Pleistocene inferred from large mammal communities, and implications for hominin dispersal in Europe, in CARrion J., Rose J. \& STRInger J. (eds), Ecological scenarios for human evolution during the Early and early Middle Pleistocene in the western Palaearctic. Special Issue of Quaternary Science Reviews 30 (1112): 1368-1395. http://dx.doi.org/10.1016/j.quascirev.2010.07.020

Koepfli K.-P., Deere K. A., Slater G. J., Begg C., BegG K., Grassman L., Lucherini M., Veron G. \& WAYNE R. K. 2008. - Multigene phylogeny of the Mustelidae: resolving relationships, tempo and biogeographic history of a mammalian adaptive radiation. BMC Biology 6 (10): 1-22.

Kormos T. 1931. - Pannonictis pliocaenica n. g. n. sp., a new giant mustelid from the Late Pliocene of Hungary. Annalibus Instituti Regii Hungarici Geologici 29: 1-16.

Kormos T. 1933. - Neue und wening bekannte Musteliden aus dem ungarischen Oberpliozän. Folia Zoologica et Hydrobiologica 5: 129-158.

KOTSAKIS T. 1985. - Vertebrati italiani e paleogeografia: alcuni esempi. Bollettino della Società Paleontologica Italiana 24 (2-3): 225-244.

KurTÉn B. 1968. - Pleistocene mammals of Europe. Weidenfield and Nicolson, London, 317 p.

MarColini F., MAsini F. \& ARgenti P. (in press). - The rodents of the Pirro Nord fauna (Foggia, Southern Italy). Palaeontographica, Abteilung A: PalaozoologieStratigraphie.

Martelli A. 1906. — Su due mustelidi e un felide del Pliocene Toscano. Bolletino della Società Geologica Italiana 35: 596-612.

MARTIN L. D. 1989. - Fossil history of the terrestrial Carnivora, in GitTleman J. L. (ed.), Carnivore Behavior, Ecology, and Evolution. Vol. 1. Cornell University Press, Ithaca: 536-568.

MASINI F. \& SALA B. 2007. — Large and small-mammal distribution patterns and chronostratigraphic boundaries from the Late Pliocene to the Middle Pleistocene of the Italian peninsula. Quaternary International 160: 43-56.

Masini F., Petruso D., Bonfiglio L. \& Mangano G. 2008. - Origination and extinction patterns of Mammals in three central western Mediterranean is- 
lands in the Late Miocene to Quaternary. Quaternary International 182: 63-79.

Maul L., Masini F., AbBazzi L. \& Turner A. 1998. The use of different morphometric data for absolute age calibration of some South and Middle European arvicolid populations. Palaeontographia Italica 85: 111-151.

Napoleone G., Albianelli A., AzZaroli A., Bertini A., Magi M. \& MAzzini M. 2003. - Calibration of the Upper Valdarno Basin to the Plio-Pleistocene for correlating the Apennine continental sequences. Il Quaternario 16: 131-166.

Ogino S. \& Otsuka H. 2008. - New middle Pleistocene Galictini (Mustelidae, Carnivora) from the Matsugae cave deposits, northern Kyushu, west Japan. Paleontological Research 12: 159-166.

Pavia G., Bertok C., Ciampo G., Di Donato V., Martire L., Masini F., Pavia M., Santangelo N., Taddei Ruggiero E. \& Zunino M. 2010. - Tectono-sedimentary evolution of the Pliocene to Lower Pleistocene succession of the ApricenaLesina-Poggio Imperiale quarrying district (western Gargano southern Italy). Italian Journal of Geoscience 129: 132-155.

Pavia M., Zunino M., Coltorti M., Angelone C., ArZarello M., Bagnus C., Bellucci L., Colombero S., Marcolini F., Peretto C., Petronio C., Petrucci M., Pieruccini P., Sardella R., Tema E., Villier B. \& PaVia G. 2012. - Stratigraphical and palaeontological data from the Early Pleistocene Pirro 10 site of Pirro Nord (Puglia, south eastern Italy). Quaternary International 267 (26): 40-55. http:// dx.doi.org/10.1016/j.quaint.2010.12.019

Peigné S., De Bonis L., Likius A., Mackaye H. T., Vignaud P. \& Brunet M. 2008. — Late Miocene Carnivora from Chad: Lutrinae (Mustelidae). Zoological Journal of the Linnean Society 152: 793-846.

Petrucci M., Cipullo A., Martinez-Navarro B., RoOK L. \& SARDELla R. (in press). - The Late Villafranchian (Early Pleistocene) carnivores (Carnivora, Mammalia) from Pirro Nord (Italy). Palaeontographica, Abteilung A: Palaozoologie-Stratigraphie.

Pilgrim G. E. 1932. - The genera Trochictis, Enhydrictis and Trocharion, with remarks on the taxonomy of the Mustelidae. Proceedings of the Zoological Society of London 4: 845-867.

Pocock R. I. 1921. - On the external characters and classification of the Mustelidae. Proceedings of the Zoological Society of London 91 (4): 803-837.

QIU Z., Deng T. \& Wang B. 2004. - Early Pleistocene mammalian from Longdan, Dongxiang, China. Palaeontologia Sinica. New Series C 27: 1-198.

Rabeder G. 1976. - Die Carnivoren (Mammalia) aus dem Altpleistozan von Deutsch-Altenburg 2. Mit Beitragen zur Systematik einiger Musteliden und Caniden. Beiträge zur Paläontologie von Österreich 1: 5-119.
Ray C. E., Anderson E. \& Webb S. D. 1981. - The Blancan Carnivore Trigonictis (Mammalia: Mustelidae) in the eastern United States. Brimleyana 5: 1-36.

REIG O. A. 1956. - Note préliminaire sur un nouveau genre de mustélidé fossiles du Pléistocène de la République argentine. Mammalia 20 (3): 223-230.

ReIG O. A. 1957. - Un mustelido del genero Galictis del Eocuartario de la provincia de Buenos Aires. Ameghiniana 1 (1-2): 33-47.

Rook L. 1995. - Pannonictis nestii (Carnivora Mammalia) from the Late Villafranchian of Pietrafitta (Umbria, Italy). Preliminary note. Eclogae Geologicae Helvetiae 88: 853-864.

Rook L., Gallai G. \& Torre D. 2006. — Lands and endemic mammals in the Late Miocene of Italy: constrains for paleogeographic outilnes of Tyrrhenian area. Palaeogeography, Palaeoclimatology, Palaeoecology 238: 263-269.

RoOK L. \& Martínez-Navarro B. 2010. - Villafranchian: the long story of a Plio-Pleistocene European large mammal biochronologic unit. Quaternary International 219: 134-144.

SCHAUB S. 1949. - Révision de quelques carnassiers villafranchiens du niveau des Étouaires, montagne de Perrier, Puy-de Dôme. Eclogae Geologicae Helvetiae 42 (2): 491-506.

SChreuder A. 1935.- A note on the Carnivora of the Tegelen Clay, with some remarks on the Grisoninae. Archives Néerlandaises de Zoologie 2: 73-94.

ShCHELinsky V. E., Dodonov A. E., Baigusheva V. S., Kulakov S. A., Simakova A. N., Tesakov A. S. \& Titov V. V. 2010. - Early Palaeolithic sites on the Taman Peninsula (Southern Azov Sea region, Russia): Bogatyri/Sinyaya Balka and Rodniki. Quaternary International 223-224: 28-35.

Sirakov N., Guadelli J.-L., Ivanova S., Sirakova S., Boudadi-Maligne M., Dimitrova I., Fernandez P., Ferrier C., Guadelli A., Iordanova D., IORdanova N., Kovatcheva M., Krumov I., Leblanc J.-C., Miteva V., Popov V., Spassov R., Taneva S. \& TSANOVA T. 2010. - An ancient continuous human presence in the Balkans and the beginnings of human settlement in western Eurasia: a Lower Pleistocene example of the Lower Palaeolithic levels in Kozarnika cave (north-western Bulgaria). Quaternary International 223-224: 94-106.

Sotnikova M. V., Baigusheva V. S. \& Titov V. V. 2002. - Carnivores of the Khapry Faunal Assemblage and their stratigraphic implications. Stratigraphy and Geological Correlation 4: 375-390. Translated from Stratigrafiya. Geologicheskaya Korrelyatsiya 10: 62-78.

SPASSOV N. 1997. - Villafranchian succession of mammalian megafaunas from Bulgaria and the biozonation of South-East Europe. Mémoires des Travaux de l'École Pratique des Hautes Études, Institut Montpellier. 21: 669-676. 
SPASSOV N. 1998. - Varshets and Slivnitsa - new localities of Villafranchian vertebrate fauna from Bulgaria (taxonomic composition, biostratigraphy and climatochronology). Geologica Balcanica 27 (1-2): 83-90.

Spassov N. 1999. - The Mammalian Megafauna from the Late Villafranchian Localities Varshets and Slivnitsa, Bulgaria and the Biochronology of the Villafranchian in S.-E. Europe. PhD Thesis (unpublished). National Museum of Natural History, Bulgarian Academy of Sciences, Sofia.

SPASSOV N. 2000. - Biochronology and zoogeographical affinities of the Villafranchian faunas of Bulgaria and South Europe. Historia Naturalis Bulgarica 12: 89-128.

SPASSOV N. 2003. - The Plio-Pleistocene vertebrate fauna in South-Eastern Europe and the megafaunal migratory waves from the East to Europe. Revue de Paléobiologie 22: 197-229.

TAYLOR M. E. 1974. - The functional anatomy of the forelimb of some African Viverridae (Carnivora). Journal of Morphology 143: 307-336.

Teilhard de Chardin P. \& Piveteau J. 1930. — Les mammiferes fossiles de Nihowan (Chine). Annales de Paléontologie 19: 87-119.

Tema E., LanZa R. \& Pavia G. 2009. - Palaeomagnetic study of the Pirro Nord sedimentary fill, in Angelone C. \& Zunino M. (eds), Abstract Book, Giornate di Paleontologia IX. Foggia, Apricena: 28-31; Maggio 2009: 56.

Toro-Moyano I., De Lumley H., Fajardo B., Barsky D., Cauch D., Celibert V., Grégoire S., MartiNEZ-NAVARRo B., Espigares M. P. \& Ros-Montoya S. 2009. - L'industrie lithique des gisements du Pléistocène inférieur de Barranco León et Fuente Nueva 3 à Orce, Grenade, Espagne. L'Anthropologie 113: 111-124.

Van Valkenburgh B. 1985. — Locomotor diversity within past and present guilds of large predatory mammals. Paleobiology 11: 406-428.

VAN VAlKenburgh B. 1987. - Skeletal indicators of locomotor behaviour in living and extinct carnivores. Journal of Vertebrate Paleontology 7: 162-182.

VIRET J. 1950. — Sur l'identité générique des Mustélidés fossiles désignés sous les noms de Pannonictis pilgrimi et d'Enhydrictis galictoides. Comptes Rendus sommaires de la Société géologique de France 9: 165-166.

VIRET J. 1954. - Le loess à bancs durcis de Saint-Vallier (Drôme) et sa faune de mammifères villafranchiens. Nouvelles Archives du Muséum d'Histoire naturelle de Lyon 4: 1-200.

VON DER DRIESCH A. 1976. - A Guide to the Measurement of Animal Bones from Archaeological Sites. Peabody Museum Bulletin 1. Peabody Museum of Archaeology and Ethnology, Cambridge, $136 \mathrm{p}$.

Willemsen G. F. 1988. — Mustela and Enhydrictis (Carnivora, Mustelidae) from Tegelen (The Netherlands). Proceedings of the Koninklijke Nederlandse Akademie Van Wetenschappen Series B Physical Sciences 83: 310-326.

Willemsen G. F. 1992. - A revision of the Pliocene and Quaternary Lutrinae from Europe. Scripta Geologica 101: 1-115.

WilsON D. E. \& REEDER D. A. M. (eds) 2005. - Mammal Species of the World. A Taxonomic and Geographic Reference. 3rd ed. Johns Hopkins University Press, Baltimore, $142 \mathrm{p}$.

WOLSAN M. \& SATO J. J. 2010. - Effects of data incompleteness on the relative performance of parsimony and Bayesian approaches in a supermatrix phylogenetic reconstruction of Mustelidae and Procyonidae (Carnivora). Cladistics 26: 168-194.

ZDANSKY O. 1927. - Weitere Bemerkungen über fossile Carnivoren aus China. Palaeontologia Sinica C 4 (4): 1-30.

Submitted on 13 July 2010; accepted on 6 May 2011. 